\title{
NEWSLETTER 1998
}

\section{ACCESSIONS TO REPOSITORIES}

The Historical Manuscripts Commission seeks each year to collect information relating to manuscript accessions from over 250 repositories and record offices throughout the British Isles. This information is then published on the internet via the Commission's web site (http:// www.hmc.gov.uk) and in a series of thematic digests which appear in a wide range of learned journals and news sheets. It is also added to the indexes to the National Register of Archives (NRA), which are available for public consultation in the Commission's search room at Quality House, Quality Court, Chancery Lane, London WC2A 1HP, or via the Commission's web site. The Commission will also answer limited and specific postal and e-mail enquiries. Readers should note that some deposits may not yet be fully listed and the appearance of a collection in this digest does not necessarily mean that it will be available for research. Further enquiries regarding access should be addressed to the staff of the relevant repository.

\section{Major Accessions to Repositories in 1997 relating to Roman Catholicism}

\section{NATIONAL. UNIVERSITY AND SPECIAL REPOSITORIES}

Scottish Catholic Archives, Columba House, 16 Drummond Place, EDINBURGH EH3 6PL

Martin McCluskey, priest: personal papers

Archdiocese of St. Andrews and Edinburgh (addnl): deeds and papers rel to the Archdiocesan Council of Priests

Diocese of Argyll and the Isles (addnl): records incl letter book of Bishop Angus MacDonald

Diocese of Dunkeld: Bishop Logan's episcopal files

Diocese of Motherwell: records incl papers rel to the Scots Foundation in France 1815-1930

St. Catherine's parish, Edinburgh: records incl priest's personal papers

St. Patrick's parish, Edinburgh: records incl Vicar General's papers 1920-29

Holy Cross School, Edinburgh: records

Scottish Catholic International Aid Fund: records incl committee and project papers

\section{LOCAL. REPOSITORIES IN ENGLAND}

Cheshire Record Office, Duke Street, Chester CH1 1RL 
Holy Name of Jesus Roman Catholic Church, Oxton, Wirral: records 1909-71 (ERC29)

Our Lady and St. Joseph's Roman Catholic Church, Wallasey: records 1864-1992 (ERC26)

St. Alban's Roman Catholic Church, Wallasey: records 1848-1996 (ERC27)

St. Joseph's Roman Catholic Church, Upton, Wirral: records 1924-80 (ERC28)

Hampshire Record Office, Sussex Street, Winchester, Hampshire SO23 $8 \mathrm{TH}$

Catenian Association, Winchester Circle: minutes and papers 1952-96 (2M97W)

Sheffield Archives, 52 Shoreham Street, Sheffield S1 4SP

Gerald Moverley, Bishop of Hallam: papers 1980-96

Tower Hamlets Local History Library and Archives, Bancroft Library, 277 Bancroft RoAd, LoNdon E1 4DQ

Guardian Angels Roman Catholic Primary School, Mile End: records c1874-1990 (I/GUA)

Tyne and Wear Archives Service, Blandford House, Blandford Square, NewCASTle upon Tyne NE1 4JA

Our Lady Queen of Peace Roman Catholic Church, Penshaw: registers 1921-73 (C/PE4)

Wigan Archives Service, Town Hall, Leigh WN7 2DY

St. Benedict's Roman Catholic School, Hindley: log books 1867-1924 (SR97)

St. William's Roman Catholic School, Ince-in-Makerfield: log books 1876-1960 (SR99)

St. Richard's Roman Catholic School, Atherton: records 1888-1905 (SR101)

\section{LOCAL REPOSITORIES IN SCOTLAND}

Ayrshire Archives, County Buildings, Wellington Square, Ayr KA7 1DR

Papal Bull of Clement VI 1348

\section{BIBLIOGRAPHY (Literary)}

Compiled by Nancy Pollard Brown. Items are included which provide information on the work of Catholic writers from the mid-sixteenth 
century to the mid-nineteenth century, and on the history of Catholic manuscripts and printed books. The area of reference is enlarged to include significant studies of major Catholic writers even when these are not primarily concerned with their religious beliefs, general studies on publishers and printers who produced recusant literature, and editions of texts and critical comment on genres and themes to which Catholic writers made important contributions.

BALDWIN, William. 'Beware the Cat' by William Baldwin: The First English Novel. Ed. William A. Ringler Jr. and Michael Flachmann. San Marino, CA: Huntington Library Press, 1995.

BALLASTER, Ros. 'Fiction Feigning Femininity: False Counts and Pageant Kings in Aphra Behn's Popish Plot Writings', 50-56 in Janet Todd, ed., Aphra Behn Studies. Cambridge: Cambridge University Press, 1996.

BARKER, Jane. The Galesia Trilogy and Selected Manuscript Poems of Jane Barker. Ed. Carol Shiner Wilson. New York and Oxford: Oxford University Press, 1997.

BARROLL, Leeds. 'Theatre as Text: The Case of Queen Anna and the Jacobean Court Masque', 175-93 in A. L. Magnusson and C. E. McGee, eds., The Elizabethan Theatre XIV. Toronto, Canada: Meany, 1996.

BAUMGAERNTER, Jill Peláez. 'Political Play and Theological Uncertainty in the Anniversaries', John Donne Journal, 1994, 29-49. (Treatment of Catholic Church in The Second Anniversarie.)

BOWERS, Toni. 'Jacobite Difference and the Poetry of Jane Barker', English Literary History, Winter 1997, 857-69.

BRACKETT, Virginia. 'Sharp Necessities', Women and Language, Fall 1996, 7-13. (Includes discussion of Elizabeth Cary, Viscountess Falkland.)

CANTAR, Brenda. 'Monstrous Conceptions and Lodge's Robin the Devil', Studies in English Literature 1500-1900, Winter 1997, 39-53.

CLANCY, Thomas H., S.J. English Catholic Books 1641-1700: A Bibliography. Rev. Ed. Aldershot and Brookfield, VT: Scolar Press, 1996.

CLARK, J. C.D. 'Religious Affiliation and Dynastic Allegiance in Eighteenth-Century England: Edmund Burke, Thomas Paine, and Samuel Johnson', English Literary History, Winter 1997, 1029-67.

COLLINSON, Patrick. 'Ecclesiastical Vitriol: Religious Satire in the 1590s and the Invention of Puritanism', 150-70 in John Guy, ed. and introd., The Reign of Elizabeth I: Court and Culture in the Last Decadeglo. Cambridge: Cambridge University Press, in association with the Folger Institute, 1995.

CREASER, John. 'Milton: The Truest of the Sons of Ben', 158-83 in Margo Swiss and David A. Kent, eds., Heirs of Fame: Milton and Writers of the English Renaissance. (Milton's sources in Ben Jonson.) 
CURLEY, Thomas M. 'Johnson as Jacobite; Or, Treason Not Yet Unmasked', The Age of Johnson, 1996, 137-62.

DODD, William. 'Power and Performance: Measure for Measure in the Public Theatre of 1604-1605', Shakespeare Studies, 1996, 211-40. (Play in relation to Gunpowder Plot.)

DOLAN, Frances E. “"Gentlemen, I Have One Thing More to Say": Women on Scaffolds in England, 1563-1680', Modern Philology, November 1994, 157-78. (Martyrdom compared to Elizabeth Cary, Viscountess Falkland, Mariam, The Fair Queen of Jewry.)

DONNE, John. John Donne's 1622 Gunpowder Plot Sermon: A Parallel Text Edition, transcribed and edited by Jeanne Shami. (Duquesne Studies in Language and Literature Series 22.) Pittsburgh, PA, 1996.

ERSKINE-HILL, Howard. 'Johnson the Jacobite? A Response to the New Introduction to Donald Greene's The Politics of Samuel Johnson', The Age of Johnson, 1996, 3-26.

FLEISSNER, Robert F. 'Virgin-to-Virgin: Did Shakespeare Really Shift from One Cult to Another?' Marianum, 1995, 369-73.

GABRIELI, Vittorio. 'John Donne, Thomas More e Roma', Rivista di Letterature Moderne e Comparate, 1995, 235-62. (Study of Donne's relationship with Catholic Church.)

GREENE, Donald. 'Johnson: The Jacobite Legend Exhumed. A Rejoinder to Howard Erskine-Hill and J. C. D. Clark,' The Age of Johnson, 1996, 57-135.

HEALY, Thomas. 'Selves, States, and Sectarianism in Early Modern England,' English, Autumn 1995, 193-213. (Treatment of Catholicism with reference to Middleton and Rowley, The Chageling, 1653.)

JACKSON, Ken. 'Bedlam, The Changeling, The Pilgrim and the Protestant Critique of Catholic Good Works', Philological Quarterly, Fall 1995, 373-93. (Treatment of Catholic charity in Middleton and Rowley, The Changeling, and John Fletcher, The Pilgrim.)

LEWIS, Jayne Elizabeth. 'Hamilton's “Abdication", Boswell's Jacobitism and the Myth of Mary Queen of Scots', English Literary History, Winter 1997, 1069-90.

LIPKING, Lawrence. 'The Jacobite Plot', English Literary History, Winter 1997, 843-55.

LODGE, Thomas. Rosalind. Euphues' Golden Legacy Found After His Death in His Cell at Silexedra (1590). Ed. with Introduction and Notes by Donald Beecher. Publications of the Barnabe Riche Society, Vol. 7. Ottawa, Canada: Dovehouse Editions, Inc., 1997.

LODGE, Thomas. Rosalynd. Ed. Brian Nellist, with the assistance of Simône Batin. Ryburn Renaissance Texts and Studies. Keele, Staffordshire: Keele University Press, 1995.

LUPTON, J. R. Afterlives of the Saints: Hagiography, Typology and Renaissance Literature. Palo Alto, CA: Stanford University Press, 1996. 
McEACHERN C. and D. SHUGER, eds. Religion and Culture in Renaissance England. Cambridge: Cambridge University Press, 1997.

McGEE, C. E. 'More than One Way to Skin a Cat(holic: Editing the Afterlife of an Occasional Entertainment', Research Opportunities in Renaissance Drama, 1995, 1-14.

MacLEAN, Gerald, ed. Culture and Society in the Stuart Restoration. Cambridge: Cambridge University Press, 1995.

MARCEAU, William C., C.S.B. 'Recusant Translation of Saint Francis de Sales', Downside Review, July 1996, 221-33.

MAROTTI, Arthur F. Manuscript, Print, and the English Renaissance Lyric. Ithaca and London: Cornell University Press, 1995. (Includes work by Katherine Thimelby.)

MELL, Donald C., ed. and introd. Pope, Swift, and Women Writers. Newark, Del.: University of Delaware Press; London: Associated University Presses, 1996.

MILLER, N. J. 'Domestic Politics in Elizabeth Cary's The Tragedy of Mariam', Studies in English Literature 1500-1900, Spring 1997, 353-70.

MORILLO, John. 'Seditious Anger: Achilles, James Stuart, and Jacobite Politics in Pope's Iliad Translation,' Eighteenth-Century Life, May 1995, 38-58.

MOSS, Ann. Printed Commonplace-Books and the Structuring of Renaissance Thought. Oxford: Clarendon Press, 1996.

MUNNS, Jessica. "The Golden Days of Queen Elizabeth": Thomas Shadwell's The Lancashire-Witches and the Politics of Nostalgia,' Restoration, Fall 1996, 195-216. (Includes treatment of Catholicism.)

OWEN, Susan J. Restoration Theatre and Crisis. Oxford: Clarendon Press, 1996. (Study of effect of Popish Plot on drama in theatre seasons 1678-83.)

PAIGE, Linda Rohrer. "A Stranger in a Strange Land": Biblical Typology of the Exodus in Dryden's The Spanish Friar; Or the Double Discovery', Papers on Language and Literature, Summer 1996, 263-76.

PARRISH, Paul A. 'Milton and Crashaw: The Cambridge and Italian Years', 208-29 in Margo Swiss and David A. Kent, eds. Heirs of Fame: Milton and Writers of the English Renaissance.

PARRY, Graham. The Trophies of Time: English Antiquarians of the Seventeenth Century. Oxford: Oxford University Press, 1995. (Discussion of Richard Verstegan.)

PERSONS, Robert. A Christian Directory, 1582. Victor Houliston, ed. Amsterdam: Brill, 1998.

SCHRICKX, Willem. 'Anthony Munday in the Netherlands in October 1595,' Notes and Queries, December 1997, 484-85.

$\mathrm{SCHOCH}$, Richard W. '(Im)pressing Texts and Spectacular Performance: The Quarrel between Ben Jonson and Inigo Jones', Constructions, 1994, 1-12. 
SHAMI, Jeanne. 'Donne's 1622 Sermon on the Gunpowder Plot: His Original Presentation Manuscript Discovered,' English Manuscript Studies 1100-1700, 1995, 63-86.

SHELL, Alison. 'Popish Plots: The Feign'd Curtizans in Context', 3149 in Janet Todd, ed., Aphra Behn Studies. Cambridge: Cambridge University Press, 1996.

SMITH, James M. 'Effaced History: Facing the Colonial Contexts of Ben Jonson's Irish Masque at Court', English Literary History, Summer 1998, 297-313.

SORLIEN, Robert Parker. 'Apostasy Reversed: Donne and Tobie Matthew', John Donne Journal, 1994, 101-12.

SULLIVAN, Ceri. Dismembered Rhetoric: English Recusant Writing, 1580-1603. Madison, NJ: Fairleigh Dickinson University Press; London: Associated University Presses, 1995.

SWISS, Margo, and David A. KENT, eds. Heirs of Fame: Milton and Writers of the English Renaissance. Lewisburg: Bucknell Univeristy Press; London: Associated University Presses, 1995.

WILCOX, Helen, Richard TODD and Alisdair MacDONALD, eds. Sacred and Profane: Secular and Devotional Interplay in Early Modern British Literature. Amsterdam: VU University Press, 1996. (Includes studies of Robert Southwell and Richard Crashaw.)

\section{FORTHCOMING:}

SHELL, Alison. Catholics, Controversy and the English Literary Imagination, 1558-1660. Cambridge: Cambridge University Press, 1999.

\section{BIBLIOGRAPHY (Historical)}

Compiled by Dr. Alan Davidson. (Bibliographical information should be sent to Dr. Davidson at 37 Vernon Avenue, Raynes Park, London, SW20 8BN).

\section{GENERAL}

CONNELLY, Roland, Women of the Catholic Resistance in England 1540-1680 (Pentland Press, 1998).

REES, Daniel (ed.), Monks of England (Downside, 1997).

St. Osmund's and Catholic Salisbury (1998).

\section{TUDOR}

LITZENBERGER, Caroline, The English Reformation and the laity: Gloucestershire, 1540-1580 (Cambridge Univ. Press, 1997). 
LUNN, David, The Catholic Elizabethans (Downside, 1997).

PERSONS, Robert, ed. Victor Houliston, The Christian Directory (1582) (Studies in the History of Christian Thought 84, Brill, 1998).

\section{STUART}

LITTLE, Patrick, "Blood and Friendship": the Earl of Essex's protection of the Earl of Clanricarde's interests, 1641-6', Eng. Hist. Rev. 112 (1997), pp. 927-41.

QUESTIER, Michael, 'The Politics of Religious Conformity and the Accession of James I', Bull. Inst. Hist. Research 71 (1998), pp. 1430.

SANDEMAN, Frideswide, Dame Gertrude More (Gracewing, 1997/8).

\section{HANOVERIAN}

The Registers of the Neapolitan Chapel, London 1764-1855. The Registers of the Imperial Chapel, London 1764-1820 (Catholic Family History, Occasional publication 2 [1997]).

\section{SCOTLAND}

DEAN, Ann, 'George Archangel Leslie, Il Cappucino Scozzese', Innes Review 49 (1998), pp. 66-76.

DILWORTH, Mark, 'Scottish Cistercian monasteries and the Reformation' Innes Review 48 (1997), pp. 144-64.

FITZGIBBON, Gerald, 'Robert Munro, secular priest in the Highlands (1645-1704)', Innes Review 48 (1997), pp. 165-73.

\section{WALES}

CUNNANE, James, 'Ceredigion and the Old Faith', Ceredigion: Jnl. Of Ceredigion Antiq. Soc. 12 (1994).

MURPHY, Martin, 'Maria's Dreams: Lady Mary Herbert, 1685-1775', Montgomeryshire Collections 85 (1997), pp. 87-100.

\section{THESES COMPLETED}

SEGUIN, Colleen Marie, “"Addicted Unto Piety": Catholic Women in England, 1590-1690' (Duke Univ., Durham, North Carolina Ph.D., 1997). 


\section{A THOMAS MORE ICON}

\section{by Rosemary RENDEL}

For the first time, all five Thomas More family group portraits 'after' Holbein have been printed together in colour, alongside the original draft sketch now at Basle, for ease of comparison. This booklet is thus a 'must' for anyone interested in Thomas More and his descendants and in the way in which the latter cherished his memory through many natural hazards and the injustices arising out of their recusancy. They did this through the family portrait copies and one is inclined to accept Lesley Lewis' suggestion that the group portrait became almost an icon. The copies may have been commissioned with that in mind. One is amazed at the way, when houses went up in flames, or were otherwise demolished, the group portraits within them seemed to survive. It is particularly sad, therefore, that when the original watercolour (distemper on cloth), came to rest with the bishop of Olmutz (now in Czechoslovakia), it should have been finally destroyed in the eighteenth century when the episcopal palace was burnt down. One would love to know how and why the bishop acquired it: it shows perhaps the enormous reputation Thomas More had on the continent and, indeed, internationally, as he has today.

Lesley Lewis takes the reader on a detailed tour of the related drawings and explains how they fitted with the original family portrait. There is an introduction to the copies in general and then to each copy individually, with information on the family context. She gives a chapter on Rowland Lockey, which will be new to most people. Her arguments in favour of the group of copies being commissioned from him in about 1593 is very persuasive and supported by recent, new technical information. She ends with the National Portrait Gallery and the Chelsea copies.

There are of course still many gaps in the story and, hopefully, other people will come forward with fresh information, to fill them: the booklet is, in some sense, a detective story and a rather fascinating one. This reviewer admits that until she read the author's description of Holbein's original watercolour, she had no idea of the lightness, sparkle and vivid immediacy it must have possessed and the original sensation it must have caused. Alas, one can only imagine these qualities, for the copies cannot reproduce them in oil. In discussing one branch of the descendants of Thomas More, the author has misread William Byrd for Christopher Bird, in the family tree given in the N.P.G. Catalogue of the Thomas More exhibition of the 1970's. Christopher Bird is most probably a nephew of William Byrd and married a great granddaughter of Thomas More. 
This booklet is certainly a valuable addition to the Thomas More literature and most enjoyable to read.

The Thomas More Family Group Portraits After Holbein by Lesley Lewis, F.S.A. for the Thomas More Picture Trust [Gracewing/Fowler Wright Books, ISBN 085244 4664, £4.99]

\section{A FORGOTTEN COLLEGE}

\section{by Mgr. Michael E. Williams}

This is an account of what is perhaps the least known of those Irish colleges in Spain that were founded for the education of the Catholic clergy during penal times. Patricia O Connell has not only consulted archives in Spain but has made good use of the archives of the Royal College of Irish Nobles in Salamanca which are now preserved at St. Patrick's College, Maynooth. This together with her knowledge of Maria José Arnaiz and José Luis Sancho's documented history of the college and its architectural features, El Colegio de Los Irlandases which appeared in 1985, make it the most up to date account of the College.

The College was first planned in 1642 by a Portuguese nobleman, and his widow set up the foundation in 1649. Its first students came from the Irish College at Santiago de Compostela and it was incorporated into the larger and better known Irish College at Salamanca in 1785. Of this brief existence of 136 years, the first fifty are very sparsely documented which means that most of our knowledge is confined to the eighteenth century. But despite the scarcity of information the author is able to reconstruct an interesting account of life in the College. It was always a small institution and its members rarely surpassed the thirty students originally intended. Dr. O Connell has drawn up a list of 177 students who entered the college between the years 1707 and 1785 together with biographical notes and the dioceses from which they originated. From other sources than those of the College which are preserved at Salamanca she is able to add further names and estimates that during the course of its short life some 300 or more students must have passed through its doors.

As was the custom in many of the Irish overseas colleges seminary training often took place after ordination in secret at home. However there were other features of Alcalà that were not so common. Unlike many of the colleges abroad Alcalà College was never under the direction of the Jesuits. The Rector, who was responsible for the running of the College and day to day matters of finance and discipline, was elected every four years by the students. This often meant that men with little experience of administration were chosen and they soon became the object of complaints. However a safeguard came from a provision in the founder's will whereby the superiors of certain religious houses in Madrid, Dominican, Benedictine and Trinitarian, were patrons and 
thus exercised some control. In theory the rectorship was rotated among collegians from the four ecclesiastical provinces, Ulster, Munster, Leinster and Connaught. Ultimately the King took over the patronage in 1770 and the rector was nominated by royal decree. The students came from dioceses in the four provinces. They were provided with viaticum, travelling expenses back to Ireland after completion of their studies. As was the custom in all colleges attached to the university, there was a distinctive college garb. We have information about such things as the heating and lighting (or lack of it) and the food they ate but unfortunately there is little about the daily timetable or actual course of studies. At the beginning there were two tutors in the house, but sometimes there were more and at other times only one. Lectures at the University were attended but as with many other overseas colleges there was fairly frequent questioning as to the relevance of the studies to their future work in Ireland. That future is graphically and movingly described in the final chapter where an assessment is made of the role of the continentally trained priest in Irish history.

This book is highly commendable not only for the light it throws on an almost forgotten institution but for the questions it raises. Reference is made to the 'one event which did not take place, the much talked of takeover of the Scotch College Madrid by the Irish College at Alcalà de Henares.' I have treated this fully from the English point of view in my St. Alban's College Valladolid. Four Centuries of English Catholic Presence in Spain, pp.91-95. After the expulsion of the Jesuits from Spain, Philip Perry and John Geddes were sent out by their respective Vicars Apostolic to reclaim and restart the English College in Valladolid and the Scots College in Madrid. This brought them into conflict with Francis O'Lean (referred to as Lane in English and Scots documents) the Rector of Alcalà and the subsequent transfer of the Scots to Valladolid. Apart from the heightened feelings that were aroused there is a more general point. Is the time ripe for further research into the reason why there was so little collaboration between the Catholics of England, Ireland and Scotland during the time when all three nations were persecuted by the same government? Can the blame be simply laid at the door of our different temperaments? There were marked differences between the social and religious conditions in the three countries, was this the reason for separate colleges in Rome, the Low Countries, Spain and Portugal? It would appear from the point of view of Rome (both Propaganda Fide and the Jesuits) and Catholic powers like France and Spain that outsiders saw the British Isles as a whole and regarded the cause of Catholicism as identical and one. At times it was even suggested that there should be one British College. Were outsiders wrong in their assessment and did the existence of separate national colleges testify to a deep rooting of Catholicism in the 
diverse peoples of the British Isles? And what effects did this have on the Welsh who never had a college of their own?

The Irish College at Alcalà de Henares 1649-1785 by Patricia O'Connell [Four Courts Press, 1997, ISBN 1-85182-345-X, £19.95].

\section{MONKISH BUSINESS \\ by Colmán Ó Clabaigh, O.S.B.}

The 1400th anniversary of St. Augustine's mission to England coupled with the centenary of St. Benet's Hall in Oxford meant that 1997 was a most productive year for English Benedictine history. Monks of England may be regarded as the official commemoration of the arrival of the monk missionary in Kent in 597, being commissioned by the 1993 General Chapter of the English Benedictine Congregation. 'Monk' and 'mission' are the recurrent leitmotifs in this work as the fifteen contributors explore the ways in which the Benedictines lived out their two vocations in different and often difficult times and circumstances.

The volume brings together many of the leading religious historians in England as well as introducing the work of younger scholars. The concentration on the themes of mission and monasticism gives the collection a unity that might easily have been lost. The work succeeds admirably in providing a clear and comprehensive survey of English Benedictine history, and though it does not claim to be a work of original scholarship, many of the chapters are obviously the products of original research by specialists.

Though it is invidious to single out individual contributions for particular attention, this reviewer was particularly struck by a number of items. Oswald McBride's enthusiastic account of the monastic revival of the tenth-century catches the spirit of this autumn flowering while Dunstan O'Keeffe's account of the expansion of the Cistercian movement before 1350 has about it the air of a new spring. The latter also gives a useful summary of the contribution made by the English Cistercian writers to the spirituality of the period. It is regrettable that the history of the White Monks after 1350 was not covered in this or in another contribution.

Anthony Marret-Crosby's piece on the re-invigoration of monasticism which occurred in the wake of the Norman conquest is an admirable presentation by one obviously in his element in the Angevin world while Joan Greatrex's essay on the cathedral priories in the later middle ages is one of the most original in the volume. Drawing on her unparalleled knowledge of the personnel of these characteristically English institutions, she presents a comprehensive account of their activities and her sections on their educational arrangements and pastoral activities are particularly interesting. The short-lived Benedictine cathedral 
chapter at Christ Church, Dublin (c.1085-1096) needs to be added to Monreale in Sicily and Downpatrick in Ireland as another example of this type of cathedral monastery outside England.

Peter Cunich's account of the dissolution of the monasteries and the fate of their inmates succeeds in being both original and moving. The spirited attempts made by the abbesses of Godstow and Amesbury to save their communities demonstrate that the mulier fortis is not just a recent monastic phenomenon while the account of the executions of Abbots Cook, Marshall and Whiting in 1539 as a means of undermining the resistance of the remaining monasteries makes chilling reading.

The emergence of English Benedictine life on the continent and the manner in which the changed circumstances of the Catholic community in England affected the constitution of these communities are the subject of essays by David Lunn and Geoffrey Scott. Aidan Bellenger's contribution on developments after the French Revolution shows the extent to which the communities were able to adapt to changed circumstances. The expansion of the field of missionary activity to the southern hemisphere during this period is of particular interest.

Augustine Clark's fine essay on the return to the monasteries provides an insightful and occasionally humorous account of the difficulties of reconciling the newly awakened monastic revivalism with the demands of the English mission. This essay and the final piece by Daniel Rees on the monastic mission in the twentieth century, illustrate the deftness of touch and depth of understanding which historians who are themselves monks bring to this volume. This is particularly true in the case of Rees who provides a clear and unflinching survey of the strengths and difficulties of the followers of St. Benedict in late twentieth century Britain.

One of the few weaknesses of the book is its complete reliance on the text to convey its message. In a work ostensibly geared to a nonspecialist readership the absence of any illustrations or maps is a major drawback. The locations of Glastonbury, Dieulouard and Downside may be well known in English Benedictine circles but it is unrealistic to expect the same familiarity elsewhere. In a work which stresses the continuity of the English monastic tradition it is very strange not to find an index. This makes it impossible to trace the development of, for instance, the English Benedictine nuns without reading each article. The decision not to treat the history of the nuns separately is unfortunate given the current widespread interest in women's history. The history of the Brussels community, the oldest of the convents, is dealt with in thirty-one words and consists of a list of the places they settled in before they were disbanded in 1975. The well-documented difficulties of this community during their time at East Bergholt are not mentioned and would have provided an interesting illustration of the experiences of English Benedictine women at the beginning of this century. 
Like the scribe in the Gospel Monks of England brings out of storage 'treasures both old and new.' It is to be highly recommended and all involved in its production to be congratulated.

Monks of England: The Benedictines in England from Augustine to the Present Day, ed. Daniel Rees, (SPCK London 1997), pp. xii+258, £27.50

\title{
THE FORTY-FIRST ANNUAL CONFERENCE OF THE CATHOLIC RECORD SOCIETY
}

\author{
by Peter B. Nockles
}

This year's conference, (held at Plater College, Oxford, from 27 to 30 July), got off to a lively start with a stimulating talk, illustrated by slides of superb visual quality, from the art historian Dr. John Bernasconi, on Feasting and drinking in Italian renaissance art.

The main seven lectures, for which Dom Aidan Bellenger's general introuction on the first evening served as a perfect appetiser, ranged widely in coverage and content over four centuries. A highlight of the conference was Dr. Victor Houliston's lecture on Robert Persons' satirical attack on William Cecil, the Lord Treasurer in his Philopater of 1592. Houliston, the recent author of a critical edition of the first version of Persons's The Christian Directory (1582) gave a fascinating account of Persons's rhetorical strategies in a work much neglected in the historical accounts of the propaganda of the early 1590s. Quoting from his own translation of Persons's Latin text, Houliston convincingly showed that the mythical portrait which Persons created of Cecil was a satirical achievement of the first order.

Dr. David Butler, a Methodist minister and ecumenical officer, and author of Methodists and Papists (DLT, 1995), gave a judicious lecture, supported by careful quotations, in which he purported to draw out points of affinity as well as contrast between two great religious contemporaries, Richard Challoner and John Wesley. Going beyond, while not overlooking, the language of theological polemic which they traded against each other's communion, Butler sought to highlight what they held in common and to show that Wesley was surprisingly close to a positive appreciation of certain aspects of Catholicism, especially in his earlier writings.

Fr. Thomas Morrissey S.J., gave a tour de force of a lecture on the theme of his recently acclaimed book As one sent: Peter Kenney S.J., 1779-1841 (Four Courts, 1996), in which he focused on Kenny's tireless missionary efforts in Ireland and North America.

Dr. Henk Dijkgraaf, a Dutch scholar, lectured on the efforts of government pursuivants at the time of the Popish Plot in 1679 to flush out a small community of Jesuits from Holbeck Hall, Nottinghamshire. The Jesuits there were the guests of Gervase and Elizabeth Pierrepoint, the son and daughter of Robert Pierrepoint, first Earl of Kingston. 
Dijkgraaf's lecture focused on the numerous searches of Holbeck Hall, the escape of one Jesuit, William Ayleworth, and eventual capture and execution of another, Edward Turner. An interesting dimension of the episode was the seizure and confiscation of a Jesuit library of some 1,000 books, which, following the intervention of the Archbishop of Canterbury, William Sancroft, was transferred to Sion College in London (a catalogue was drawn up which is still extant).

Dr. Sean O'Reilly's illustrated lecture, Ecclesiology and the new Catholics: mid-Victorian church architecture and 'The Rambler', successfully showed that there were many and varied alternatives to A. W. Pugin's own dogmatic brand of the Gothic Revival among architects of mid-Victorian Catholic churches. O'Reilly argued that it was in the intellectual climate created by the so-called 'new Catholics' of the day-mainly Anglican converts-that a reaction against Pugin's rigid ecclesiastical antiquarianism, notably over rood screens, found eloquent expression. It was the liberal Catholic journal The Rambler, founded in 1848 by the convert John Moore Capes, which provided the most significant public forum for the presentation of architectural alternatives to Pugin's dogmatic blueprints. The architect George Wigley, now littleknown, was a noted contributor to its pages and was to be a key agent in the modification of Puginite Gothic designs in accordance with contemporary Roman liturgical norms. Wigley's rediscovery of St. Charles Borromeo's architectural principles was crucial in this process. His translation of Borromeo's Instructions on Ecclesiastical Buildings, was the most significant single British publication on contemporary Roman Catholic ecclesiology in the 1850s. As O'Reilly noted, The Rambler may have got into hot-water with the hierarchy over theological issues, but its artistic concerns earned wide favour both within and without the hierarchy.

The Nicole Hodgson Lecture was given by a young scholar, Michael Hutchings, on the subject of Reginald, Cardinal Pole. Hutchings's careful reassessment of Pole's life career, reforms and spirituality, revealed a deeper apologetical purpose on the part of the lecturer for whom Pole was truly 'the angelical cardinal'.

The conference was rounded off by a superb lecture, clearly and engagingly delivered by Dr. Rosemary Mitchell, which with suitable visual aids, demonstrated the extent to which Charles Dolman's illustrated 1854 edition of Lingard's History of England (first published in 8 volumes between 1819-30), revealed by means of its imagery a transition from a somewhat defensive and understated tone (as evident in Lingard's original text) to a more militant Catholic historiography.

As in previous years, some of the most rewarding moments of the conference were to be found in the informal evening sessions where researchers gave either a short communication paper or statement of work in progress and appeals for information. Two short papers in these sessions deserve especial notice-those by Emma Riley on Pugin and 
the 'Rood Screen Controversy' (touching on themes developed by Dr. O'Reilly), and by a young Spanish scholar, Pilar Garces Garcia, on the impact of English students of the English College of Valladolid on the cultural relationship between Britain and Spain in the early nineteenth century. The latter's paper was based on a scholarly analysis of a manuscript (which she intends to edit for publication) written in 1830 by an English student of the college, James Standen. The manuscript comprised a collection of fictional letters, diary and short poems, which served as a medium for the expression of the author's acute observations on and anxieties about the contemporary political and social climate in England, France and Spain. 


\section{The David Rogers Research Fund}

The CRS has established a research fund financed by a legacy from the late Dr. David Rogers. The aim of the fund is to defray the costs of travel to libraries and archives, at home and/or abroad, by researchers in the field of Reformation and post-Reformation Catholic history in the British Isles. The closing date for applications is 1 September preceding the year in which it is intended to travel. Application forms are obtainable from the Hon. Secretary CRS, 12 Melbourne Place, Wolsingham, Co. Durham, DL13 3EH, England. Intending applicants who require more details are welcome to consult the Hon. Secretary by telephone: 01388527747.

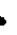

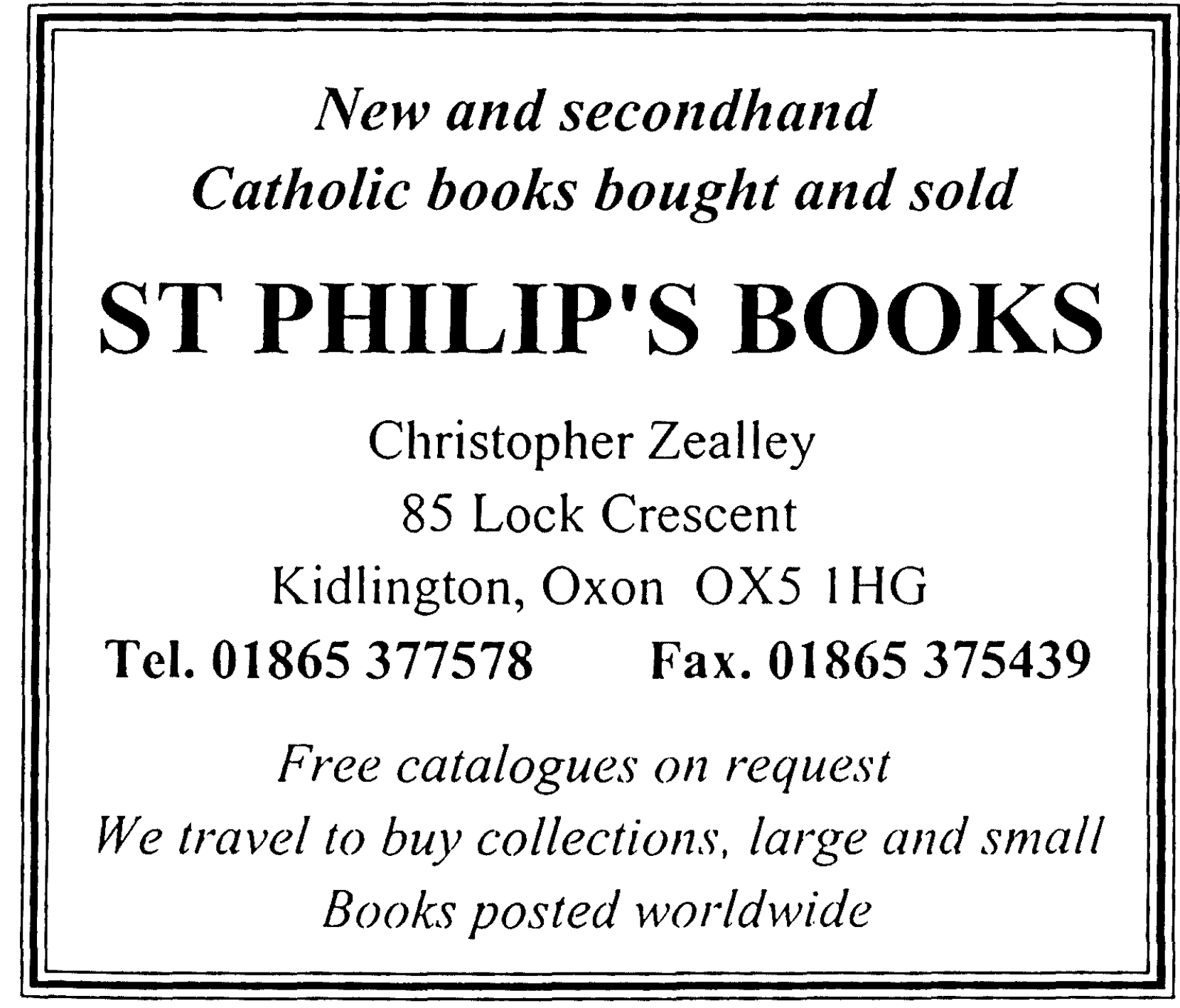




\section{Conferences in 1999}

The 1999 Annual Conference of the Catholic Record Society will be held at Plater College, Oxford, 19-22 July. Offers of papers should be made to the Conference Director: Dr. Peter Nockles, 46 Viceroy Court, Wilmslow Rd, Manchester M20 2RH. Administrative details can be obtained from the Conference Secretary: Mrs. J. Smeaton, 33 Middlethorpe Drive, York YO2 2NA. [Tel. 01904 704525]

The 1999 Annual Conference of the Catholic Archives Society will be held at Ushaw College, Durham, over the Spring Bank Holiday. Full details can be obtained from Mrs. M. HarcourtWilliams, Innyngs House, Hatfield Park, Hatfield, Herts. AL9 5PL. [Tel 01707 269516]

\section{Catalogue}

The Catalogue of CRS publications will not be reprinted; henceforth it will be available for consultation on the Internet at

\section{www.catholic-history.org.uk/crs}

Space on this site is being taken up by other societies in the UK having an interest in the Roman Catholic history of Great Britain. Details will appear on the home-page in due course. 